\title{
Mammaglobin-A DNA Vaccine
}

National Cancer Institute

\section{Source}

National Cancer Institute. Mammaglobin-A DNA Vaccine. NCI Thesaurus. Code C82675.

A cancer vaccine containing a plasmid encoding the mammag lobin-A gene with potential immunostimulating and antineoplastic activities. Upon administration, mammaglobin-A DNA vaccine may induce both humoral and cytotoxic T lymphocyte (CTL) immune responses against tumor cells that express mammaglobin-A, which may result in decreased tumor growth. The 10 kiloDalton $(\mathrm{kD})$ glycoprotein mammg lobin- $\mathrm{A}$ is expressed in over $80 \%$ of human breast cancers. 